$\begin{array}{r}\text { Phinisi Integration Review } \\ \text { Vol. 2, No.1, Februari 2019 Hal 055-066 } \\ \text { Website: http://ojs.unm.ac.id/pir } \\ \text { p-ISSN: 2614-2325 dan e-ISSN: 2614-2317 } \\ \hline\end{array}$

\title{
Pengaruh Model Pembelajaran Role Playing dan Inside Outside Circle Terhadap Hasil Belajar IPS Peserta Didik SDN 008 Camba - Camba Kabupaten Polewali Mandar
}

\author{
Nurhaida Rahman ${ }^{(1)}$ \\ Prodi IPS Ke-SD-an Program Pascasarjana Universitas Negeri Makassar \\ email: aidarahman961@gmail.com
}

\begin{abstract}
Abstrak. Penelitian ini bertujuan untuk (i) mengetahui seberapa besar hasil belajar penggunaan model pembelajaran Role Playing peserta didik kelas IV SD Negeri 008 Camba-camba; (ii) mengetahui seberapa besar hasil belajar penggunaan model pembelajaran Inside Outside Circle peserta didik kelas IV SD Negeri 008 Camba-camba; (iii) mengetahui pengaruh model pembelajaran Role Playing dan Inside Outside Circle terhadap hasil belajar peserta didik kelas IV SD Negeri 008 Camba-camba Kabupaten Polewali Mandar.Jenis penelitian merupakan pre-eksperimen, dengan model pre-test post-test one group design. Instrument penelitian berupa test hasil belajar (pretest dan posttest), dan lembar kegiatan aktivitas siswa. Data Analisis deskriptif untuk mendeskripsikan kemampuan guru mengola pembelajaran, aktivitas siswa dalam pembelajaran dan hasil belajarnya. Analisis statistik inferensial uji normalitas, uji homogenitas, uji regresi berganda dan (uji-t) digunakan untuk melihat pengaruh model pembelajaran Role Playing dan Inside Outside Circle terhadap hasil belajar ips peserta didik melalui program SPSS. Hasil penelitian menunjukkan bahwa (1) hasil belajar IPS peserta didik kelas IV di SDN 008 Camba - camba Kabupaten Polewali Mandar sebelum menggunakan model pembelajaran Role Playing dan Inside Outside Circle berada pada kategori sangat rendah (2) kemudian terjadi peningkatan hasil belajar IPS peserta didik setelah menggunakan model pembelajaran Role Playing dan Inside Outside Circle. (3) terdapat pengaruh model pembelajaran Role Playing dan Inside Outside Circle Terhadap Hasil Belajar IPS Peserta Didik Kelas IV SDN 008 Camba - camba.
\end{abstract}

Kata Kunci: Pengaruh model pembelajaran; Role Playing; Inside Outside Circle

\begin{abstract}
This study aims to (i) find out how much learning outcomes before the implementation of the learning model of Role Playing and Inside Outside Circle of students in grade IV SD Negeri 008 Camba-camba Polewali Mandar Regency; (ii) to find out how much the learning outcomes after the implementation of the Role Playing and Inside Outside Circle learning models of the fourth grade students of SD Negeri 008 Camba-camba Polewali Mandar city; (iii) to find out the influence of the Role Playing and Inside Outside Circle learning models on the learning outcomes of grade IV students of SD Negeri 008 Camba-camba in Polewali Mandar. This type of research is preexperimental, with the pre-test post-test one group design model. This research was conducted to see the effect of Role Playing and Inside Outside Circle learning models on social studies learning outcomes of students. The research instrument is in the form of learning test results (pretest and posttest), and student activity activity sheets. Data Descriptive analysis to describe the ability of teachers to learn learning, student activities in learning and learning outcomes. Inferential statistical analysis (t-test) is used to see the
\end{abstract}


effect of Role Playing and Inside Outside Circle learning models on the learning outcomes of IPS through the SPSS program. The results showed that (1) social studies learning outcomes of fourth grade students at SDN 008 Camba - camba Polewali Mandar Regency before using the Role Playing and Inside Outside Circle learning models were in the very low category (2) there was an increase in social studies learning outcomes for grade IV students. at SDN 008 Camba - camba Polewali Mandar Regency after using the Role Playing and Inside Outside Circle learning models. (3) there is an effect of Role Playing and Inside Outside Circle learning models on Social Studies Learning Outcomes of Grade IV Students of SDN 008 Camba - camba.

Keywords: Effect of Role Playing learning models; Inside Outside Circle

Ini adalah artikel dengan akses terbuka dibawah licenci CC BY-NC-4.0

(https://creativecommons.org/licenses/by-nc/4.0/ ).

\section{PENDAHULUAN}

Pendidikan merupakan suatu aspek kehidupan yang sangat mendasar bagi pembangunan bangsa suatu Negara. Dalam penyelenggaraan pendidikan di sekolah melibatkan guru sebagai pendidik dan siswa sebagai peserta didik, diwujudkan dengan adanya interaksi belajar mengajar atau proses pembelajaran. Dalam konteks penyelenggaraan ini, guru dengan sadar merencanakan kegiatan pengajarannya secara sistematis dan berpedoman pada seperangkat aturan dan rencana tentang pendidikan yang dikemas dalam bentuk kurikulum.

Berdasarkan UUD Republik Indonesia Nomor 20 Tahun 2003 Tentang Sistem Pendidikan Nasional Pasal 3 bahwa : Pendidikan nasional berfungsi mengembangkan kemampuan dan membentuk watak serta peradaban bangsa yang bermartabat dalam rangka mencerdaskan kehidupan bangsa, bertujuan untuk berkembangnya potensi peserta didik agar menjadi Manusia yang beriman dan bertakwa kepada Tuhan Yang Maha Esa, berakhlak mulia, sehat, berilmu, cakap, kreatif, mandiri, dan menjadi warga negara yang demokratis serta bertanggung jawab. Salah satu permasalahan yang dihadapi dunia pendidikan kita adalah rendahnya kualitas hasil dan proses belajar yang dicapai peserta didik. Rendahnya kualitas hasil belajar ditandai oleh pencapaian prestasi belajar yang belum memenuhi standar kompetensi seperti tuntutan kurikulum. Dalam setiap mata pelajaran termasuk pada mata pelajaran IPS, proses belajar dilakukan peserta didik terbatas pada penguasaan materi pelajaran atau penambahan pengetahuan sebagai bahan ujian atau tes. Padahal menurut tuntutan kurikulum yang berlaku, peserta didik diharapkan bukan hanya sekedar dapat mengakumulasi pengetahuan akan tetapi, diharapkan dapat mencapai kompetensi, yakni perpaduan pengetahuan, sikap, dan keterampilan.

Menurut Nasution Sumatmadja （2002:12 3) ,Bahwa IPS adalah suatu program pendidikan yang merupakan suatu keseluruhan yang pada pokoknya mempersoalkan manusia dan lingkungan alam fisik maupun lingkungan sosialnya yang bahannya di ambil dari berbagai ilmu sosial seperti : geografi, sejarah, ekonomi, antropologi, sosiologi, ilmu politik dan psikologi.

Bertolak pada peningkatan pendidikan, maka guru memegang peranan penting dalam pelaksanaan proses pembelajaran, demikian pula peserta didik yang turut memegang peranan penting dalam pencapaian tujuan pendidikan, khususnya dalam hal penerimaan materi pelajaran. Agar pembelajaran lebih efektif, guru dituntut untuk menguasai manajemen kelas. Di dalam kelas guru tidak hanya bertugas menyampaikan materi pelajaran, tetapi juga harus mampu mewujudkan suasana belajar yang menyenangkan. Oleh sebab itu, beban yang didapat oleh sekolah, dalam hal ini adalah beban guru sangat berat. Gurulah yang berada pada garis depan dalam membentuk pribadi peserta didik. Kedisiplinan belajar dapat ditanamkan kepada peserta didik melalui beberapa pembelajaran di kelas. Pilihan pembelajaran atau model pembelajaran merupakan bagian 
yang penting dan membutuhkan kejelian serta inovasi guru dalam proses transformasi ilmu pengetahuan atau nilai-nilai. Pada dasarnya manusia membutuhkan pendidikan dalam kehidupannya, baik pendidikan formal maupun pendidikan non-formal, agar dengan pendidikan potensi dirinya dapat berkembang melalui proses pembelajaran atau cara lain yang dikenal dan dilakukan oleh masyarakat. Lahirnya generasi baru yang cerdas dan handal adalah suatu keharusan bagi suatu bangsa, para pendidik (guru) serta orang tua.

Upaya meningkatkan hasil belajar peserta didik merupakan tantangan yang selalu dihadapi oleh setiap orang yang berkecimpung dalam profesi keguruan dan pendidikan. Banyak upaya yang telah dilakukan dan banyak pula keberhasilan yang telah dicapai, meskipun keberhasilan itu belum sepenuhnya memberikan kepuasan bagi masyarakat dan para pendidik, sehingga sangat menuntut renungan, pemikiran dan kerja keras orang-orang yang berkecimpung di dunia pendidikan untuk memecahkan masalah yang dihadapi.

Kemampuan guru dalam memilih dan memilah metode, yang relevan dengan tujuan dan materi pelajaran merupakan kunci keberhasilan dalam pencapaian prestasi belajar peserta didik. Tuntutan tersebut mutlak dilakukan oleh seorang guru, apabila melalukan transfer ilmu khususnya IPS. Hal tersebut juga sejalan dengan tuntutan kurikulum saat ini yang sangat memperhatikan kepentingan model pembelajaran yang akan digunakan.

\section{Pengertian Hasil Belajar}

Menurut Purwanto (2010: 46) "Hasil belajar adalah perubahan perilaku peserta didik akibat belajar. Perubahan perilaku disebabkan karena peserta didik mencapai penugasan atas sejumlah bahan diberikan dalam proses belajar mengajar. Sedangkan menurut Rifa'I dalam Anni (2009: 85) bahwa: "Hasil belajar merupakan perubahan perilaku yang diperoleh peserta didik setelah mengalami kegiatan belajar. Perolehan aspek-aspek perubahan perilaku tersebut tergantung pada apa yang di pelajari oleh peserta didik". Menurut Sanjaya (2009: 13) bahwa: "Hasil belajar berkaitan dengan pencapaian dalam memperoleh kemampuan sesuai dengan tujuan khusus yang direncanakan".

\section{Pembelajaran IPS di Sekolah Dasar}

a. Pembelajaran

Konsep dasar pembelajaran Nasution (Sugihartono,dkk, 2007: 80) mendefinisikan pembelajaran sebagai suatu aktivitas mengorganisasi atau mengatur lingkungan sebaik-baiknnya dan menghubungkan dengan peserta didik sehingga terjadi proses belajar. Lingkungan dalam pengertian ini tidak hanya ruang belajar, tetapi juga meliputi guru, alat peraga, perpustakaan, laboratorium, dan sebagainnya yang relevan dengan kegiatan belajar peserta didik.

Pembelajaran berdasarkan makna leksikal artinya proses, cara, perbuatan mempelajari. Guru mengajar pada persepktif pembelajaran adalah guru yang menyediakan fasilitas belajar bagi peserta didiknya untuk mempelajarinya. Jadi subjek pembelajaran adalah peserta didik. Pembelajaran lebih berpusat pada peserta didik (Suprijono, 2011: 13). Pembelajaran adalah Proses interaktif antara peserta didik dan guru.

Pembelajaran berdasarkan makna leksikal artinya proses, cara, perbuatan mempelajari. Guru mengajar pada persepktif pembelajaran adalah guru yang menyediakan fasilitas belajar bagi peserta didiknya untuk mempelajarinya. Jadi subjek pembelajaran adalah peserta didik. Pembelajaran lebih berpusat pada peserta didik (Suprijono, 2011: 13). Pembelajaran adalah Proses interaktif antara peserta didik dan guru. Ada beberapa komponen yang harus diperhatikan dalam proses pembelajaran. Komponen-komponen tersebut adalah tujuan, materi pelajaran, metode atau strategi pembelajaran, media, dan evaluasi (Sanjaya,2010:59).

\section{b. Pembelajaran IPS di Sekolah Dasar}

Rumusan tentang pengertian IPS telah banyak dikemukakan oleh para ahli IPS atau social studies. Di sekolah-sekolah Amerika pengajaran IPS dikenal dengan social studies. Jadi, istilah IPS merupakan terjemahan social studies. Dengan demikian IPS dapat diartikan dengan "kajian tentang masyarakat". Dalam mengkaji masyarakat, guru dapat melakukan kajian dari berbagai perspektif sosial, seperti kajian melalui pengajaran sejarah, geografi, ekonomi, sosiologi, antropologi politikpemerintahan, dan aspek psikologi sosial yang 
disederhanakan untuk mencapai tujuan pembelajaran.

Istilah Ilmu Pengetahuan Sosial (IPS) merupakan nama mata pelajaran di tingkat sekolah atau nama studi di Perguruan Tinggi yang identik dengan istilah "social studies" dalam kurikulum persekolahan di negara lain, khususnya di negara-negara Barat seperti Australia dan Amerika Serikat. Nama IPS yang lebih dikenal social studies negara lain itu merupakan istilah hasil kesepakatan dari para ahli atau pakar kita di Indonesia.

Dalam dokumen kurikulum 1975 IPS merupakan salah satu nama mata pelajaran yang diberikan pada jenjang pendidikan dasar dan menengah. Namun, pengertian IPS di tingkat persekolahan itu sendiri mempunyai perbedaan makna khususnya antara IPS untuk Sekolah Dasar (SD) dengan IPS untuk Sekolah Menengah Pertama (SMP) dan IPS untuk Sekolah Menengah Atas (SMA).

Pengertian IPS di persekolahan tersebut ada yang berarti program pengajaran, ada yang berarti mata pelajaran yang berdiri sendiri, ada yang berarti gabungan (paduan) dari sejumlah mata pelajaran atau disiplin ilmu. Perbedaan ini dapat pula diidentifikasi dari perbedaan pendekatan yang diterapkan pada masingmasing jenjang persekolahan tersebut.

\section{Pembelajaran Role Playing (bermain peran)}

Menurut Zaini, (2008: 98) "Role Playing adalah suatu aktivitas pembelajaran terencana yang dirancang untuk mencapai tujuan-tujuan pendidikan yang spesifik". Dari pendapat di atas, dapat dilihat bahwa kegiatan Role Playing merupakan kegiatan yang hampir menyerupai sebuah drama dalam hal pelaksanaannya.

Teori yang mendukung penggunaan model Role Playing dalam pembelajaran IPS terhadap hasil belajar peserta didik adalah teori belajar Vigotsky, dimana Vigotsky menyatukan bahwa "Interaksi sosial dengan teman lain memacu terbentuknya ide baru dan memperkaya perkembangan intelektual siswa". Hal ini sejalan dengan teori belajar penemuan yang dikemukakan oleh Jerome. S Brumer, "Belajar penemuan sesuai dengan pencarian pengetahuan secara aktif oleh manusia, dengan sendirinya memberikan hasil yang lebih baik, berusaha sendiri mencari pemecahan masalah serta didukung oleh pengetahuan yang menyertainya, serta menghasilkan pengetahuan yang benarbenar bermakna" (Dahar, 1989:103).

\section{(IOC)}

\section{Pembelajaran Inside Outside Circle}

Menurut Kagan, 1990 (dalam Huda, 2013: 247) IOC merupakan strategi pembelajaran dengan membuat dua lingkaran besar dan lingkaran kecil sehingga memungkinkan peserta didik untuk saling berbagi informasi dalam waktu yang bersamaan". Penerapan model pembelajaran IOC dengan persiapan yang matang dan pelaksanaan yang optimal, maka dapat memberikan hasil belajar peserta didik yang berbeda, karena peserta didik akan lebih aktif didalam kelas untuk mengemukakan pendapatnya serta lebih memahami materi yang disampaikan guru.

Teori Pembelajaran Jean Piaget. Penerapan model pembelajaran tipe IOC ini sejalan berdasarkan teori kontruktivisme. Piaget dalam Sanjaya (2009: 121) menyatakan bahwa: Pada dasarnya setiap individu sejak kecil sudah memiliki kemampuan untuk mengkonstruksikan pengetahuannya sendiri. Pengetahuan yang dikontruksikan oleh anak sebagai subjek, maka akan menjadi pengetahuan yang bermakna.

\section{METODE PENELITIAN}

\section{A. Jenis dan Desain Penelitian}

Variabel yang diamati dalam penelitian ini adalah model pembelajaran Role Playing (bermain peran) dan Inside Outside Circle (IOC) sebagai variabel bebas dan hasil pembelajaran IPS kelas IV SD Negeri 008 Camba-camba kota Polewali Mandar sebagai variabel terikat. Penelitian ini adalah penelitian kuantitatif dengan jenis penelitian Pra- Experimen model The One Group Pretest-Posttest. Dalam design ini Sugiyono menyatakan "bahwa penelitian ini adalah penelitian yang dilakukan sebanyak dua kali sebelum eksperimen (pre-test) dan sesudah eksperimen (post-test) dengan satu kelompok subjek" (Sugiyono, 2010: 414). Dimana kelebihan dari rancangan ini adalah peneliti dapat membandingkan hasil perlakuan yang diberikan, dengan adanya nilai tes awal peneliti bisa membandingkan hasilnya dengan mengobservasi dari nilai tes akhir. Karena dua model jadi peneliti menggunakan dua kelas, 
dimana masing-masing kelas diberikan soal pretest dan posttest untuk melihat perbandingan hasil belajar IPS peserta didik. Untuk lebih jelasnya tentang desain penelitian yang digunakan dalam penelitian ini, dapat dilihat pada tabel dibawah ini sebagai berikut :

Tabel 3.1 Desain penelitian The One Group Design Pretest-Posttest

\begin{tabular}{|l|l|l|}
\hline Pretest & Perlakuan & Posttest \\
\hline $\mathrm{O}_{1}$ & $\mathbf{X}$ & $\mathrm{O}_{2}$ \\
\hline
\end{tabular}

(Sugiyono, 2010: 415).

Keterangan:

$$
\begin{array}{ll}
\mathrm{O}_{1} & =\text { hasil pretest } \\
\mathrm{X} & =\text { treatmen (perlakuan) } \\
\mathrm{O}_{2} & =\text { hasil posttest }
\end{array}
$$

\section{B. Populasi dan Sampel}

Menurut Sugiyono (2010: 117) bahwa: "Populasi adalah wilayah generalisasi yang terdiri atas;objek/subjek yang mempunyai kualitas dan karakteristik tertentu yang diterapkan oleh peneliti untuk dipelajari dan kemudian ditarik kesimpulannya". Sedangkan menurut Riduwan (2010: 54) bahwa "Populasi merupakan objek atau subjek yang berada pada wilayah tertentu dan memenuhi syarat-syarat tertentu berkaitan dengan masalah penelitian". Dari kedua pengertian populasi yang telah dikemukakan di atas dapatlah disimpulkan bahwa populasi merupakan keseluruhan yang menjadi objek penelitian. Populasi dalam penelitian ini adalah seluruh peserta didik Kelas IV dengan jumlah 48 orang yang berjumlah dua kelas yaitu kelas IV A 21 orang dan kelas IV B sebanyak 28 orang.

Sedangkan Menurut Abustam, (2006: 39) sampel adalah sebagian contoh yang diambil dari popilasi. Sampel penelitian adalah siswa kelas IV di SDN 008 Camba-camba kecamatan Limboro Kabupaten Polewali Mandar. Tekhnik pengambilan sampel adalah random sampling. Yang menjadi sampel dalam penelitian ini adalah kelas IV A yang diambil secara acak dengan jumlah sampling 20 orang peserta didik dan kelas IV B yang diambil secara acak dengan jumlah sampling 20 orang peserta didik.

\section{Teknik Pengumpulan Data}

Teknik pengumpulan data sangat dibutuhkan dalam penelitian, sebab dapat menentukan keberhasilan suatu penelitian. Kualitas data ditentukan oleh kualitas alat pengumpulan data yang cukup valid. Adapun Teknik pengumpulan data yang digunakan adalah sebagai berikut:
a. Tes
b. Observasi
c. Dokumentasi

\section{Tempat dan Waktu Penelitian}

Penelitian ini dilaksanakan di SDN 008 Camba-camba Kecamatan Limboro Kabupaten Polewali Mandar pada pembelajaran IPS tahun ajaran 2018/2019. Penelitian ini dilakukan pada semester genap (I) di mulai pada 05 Oktober.

\section{E. Fokus Penelitian}

Jenis dan jumlah variabel dalam penelitian ini yaitu ada dua variabel yang terdiri dari:

1. Variabel pengaruh model pembelajaran Role Playing dan Inside Outside Circle sebagai variabel bebas $(\mathrm{X})$,

2. Variabel hasil belajar terhadap hasil belajar IPS peserta didik kelas IV sebagai variabel terikat (Y).

\section{F. Definisi Operasional Variabel}

Penelitian ini dimaksudkan untuk mengkaji dua peubah, yaitu penerapan model pembelajaran Role Playing (bermain peran) dan Inside Outside Circle (IOC) sebagai peubah bebas atau yang mempengaruhi (dependen), dan Hasil belajar sebagai peubah terikat atau yang dipengaruhi (independen). Definisi operasional merupakan batasan-batasan yang digunakan untuk menghindari perbedaan interpretasi terhadap peubah yang diteliti dan sekaligus menyamakan persepsi tentang peubah yang dikaji, maka dikemukakan definisi operasional peubah penelitian sebagai berikut:

1. Pengaruh adalah suatu daya atau kekuatan yang timbul dari sesuatu, baik orang maupun benda sehingga mempengaruhi apa-apa yang ada di sekitarnya. 
2. Model pembelajaran Role Playing atau bermain peran ini merupakan pembelajaran yang lebih menekankan pada permainan gerak dan peserta didik biasanya dilatih untuk memahami, memperagakan setiap peran-peran yang di perankannya untuk selanjutnya biasanya peserta didik ditugaskan untuk memberikan penilaian baik kekurangan atau kelebihan dari peran yang dimainkan ataupun juga jalan cerita yang di perankannya, sedangkan model pembelajaran Inside Outside Circle yang disingkat IOC adalah strategi pembelajaran dengan membuat dua lingkaran besar dan lingkaran kecil sehingga memungkinkan peserta didik untuk saling berbagi informasi dalam waktu yang bersamaan.

3. Pengaruh model pembelajaran Role Playing adalah model pembelajaran yang bermain peran atau memainkan peran berdasarkan materi pembelajaran sedangkan Inside Outside Circle adalah model pembelajaran dengan membuat dua lingkaran besar dan lingkaran kecil sehingga memungkinkan siswa untuk saling berbagi informasi dalam waktu yang bersamaan.

4. Hasil belajar IPS adalah perubahan perilaku dari peserta didik setelah mengalami kegiatan belajar. Hasil kegiatan belajar dapat di lihat pada kemampuan peserta didik dalam ranah kognitif, afektif, dan psikomotorik pada mata pelajaran IPS, penelitian ini dilakukan pada kelas IV dengan materi pada semester genap 2017/2018.

\section{G. Teknik Analisis Data}

Kegiatan dalam analisis data adalah mengelompokkan data berdasarkan variabel dan jenis responden, mentabulasi data berdasarkan variabel dari keseluruhan responden, menyajikan data dari tiap variabel yang diteliti, melakukan perhitungan untuk menjawab rumusan masalah dan melakukan perhitungan untuk menguji hipotesis (Sugiyono, 2011: 147). Untuk menganalisis data yang diperoleh dari hasil penelitian akan digunakan analisis statistik deskriptif dan inferensial.

\section{Statistik Deskriptif}

Statistik deskriptif adalah statistik yang digunakan untuk menganalisis data dengan cara mendeskripsikan atau menggambarkan data yang telah terkumpul sebagaimana adanya, tanpa bermaksud membuat kesimpulan yang berlaku umum, (Sugiyono, 2015:147).

\section{Analisis Data Statistik Inferensial}

Menurut Arikunto, (2013:350). Statistik inferensial adalah teknik statistik yang digunakan untuk menganalisis data sampel dan hasilnya diberlakukan untuk populasi. Teknik statistik ini dimaksudkan untuk menguji hipotesis penelitian. Pada tahap analisis ini, nilai yang di analisis adalah selisi antara nilai posttest dan nilai awal (nilai posttest - nilai awal). Adapun uji analisis sebagai berikut:
a. Uji Normalitas
b. Uji Homogenitas
c. Uji Regresi Berganda.

\section{H. Hipotesis Statistik}

Perumusan hipotesis statistik dalam penelitian ini adalah sebagai berikut :

$$
\begin{aligned}
& \text { Ho : } \mu_{1}=\mu_{2} \\
& \mathrm{H}_{1}: \mu_{1} \neq \mu_{2}
\end{aligned}
$$

Keterangan :

Ho = Tidak ada pengaruh terhadap hasil belajar sebelum dan sesudah menggunakan model Pembelajaran Role Playing dan Inside Outside Circle

$\mathrm{H}_{1} \quad=$ ada pengaruh hasil belajar sebelum dan sesudah menggunakan model Pembelajaran Role Playing dan Inside Outside Circle (Pretest).

\section{HASIL DAN PEMBAHASAN}

\section{A. Hasil Penelitian}

Dari hasil statistik deskriptif perhitungan hasil belajar peserta didik sebelum penggunaan model pembelajaran Role Playing masih sangat rendah dilihat dari nilai minimun siswa yaitu 40, hal ini berarti nilai peserta didik pada mata pelajaran IPS masih sangat rendah. Berikut tabel distribusi hasil belajar IPS peserta didik (pretest). 
Nurhaida Rahman. Pengaruh Model Pembelajaran Role Playing dan Inside Outside Circle Terhadap Hasil Belajar IPS Peserta Didik SDN 008 Camba - Camba Kabupaten Polewali

Mandar

Tabel 1 Rekapitulasi Hasil Belajar IPS Peserta Didik (Pretest)

\begin{tabular}{cc}
\hline & Pretest \\
\hline Ukuran sampel & 20 \\
Mean & 52,5 \\
Median & 50 \\
Mode & 40 \\
Standar deviasi & 11,65 \\
Nilai tertinggi & 70 \\
Nilai Terendah & 40 \\
\hline
\end{tabular}

Tabel 2 Rekapitulasi Hasil Belajar IPS Peserta Didik (Posttest)

\begin{tabular}{ll}
\hline & Posttest \\
\hline Ukuran sampel & 20 \\
Mean & 94 \\
Median & 100 \\
Mode & 100 \\
Standar deviasi & 7,54 \\
Nilai tertinggi & 100 \\
Nilai terendah & 80 \\
\hline
\end{tabular}

Deskripsi Hasil Belajar (Pretest) dan (Posttest) IPS Peserta Didik sebelum diterapkan Model Pembelajaran Inside Outside Circle

Adapun data yang dianalisis adalah data pretest hasil belajar peserta didik sebelum penggunaan model pembelajaran Inside Outside Circle. Data hasil belajar IPS peserta didik yang selengkapnya dapat dilihat pada Tabel 3 berikut ini.

\begin{tabular}{ll}
\hline & Pretest \\
\hline Ukuran sampel & 20 \\
Mean & 52 \\
Median & 50 \\
Mode & 50 \\
Standar deviasi & 11,97 \\
Nilai tertinggi & 70 \\
Nilai terendah & 30 \\
\hline
\end{tabular}

Sedangkan hasil belajar peserta didik dideskripsikan berdasarkan distribusi frekuensi dan persentase hasil tes akhir (postest). Data hasil belajar IPS peserta didik yang selengkapnya dapat dilihat pada Tabel 4 berikut ini.

\begin{tabular}{ll}
\hline & Posttest \\
\hline Ukuran sampel & 20 \\
Mean & 91 \\
Median & 95 \\
Mode & 100 \\
Standar deviasi & 9,68 \\
Nilai tertinggi & 100 \\
Nilai terendah & 80 \\
\hline
\end{tabular}

\section{Hasil Statistik Inferensial}

Hasil analisis statistik inferensial dilakukan untuk menguji hipotesis penelitian. Syarat yang harus dipenuhi untuk menguji hipotesis ini adalah data yang diperoleh harus berdistribusi normal serta mempunyai variansi yang homogen.

\section{1) Uji Normalitas Data}

Uji normalitas bertujuan untuk mengetahui apakah data sampel yang digunakan dalam penelitian berasal dari populasi yang berdistribusi normal. Pengelolaan data ini menggunakan bantuan software SPSS 23.0 for Windows dengan uji Tests of Normality Kolmogorov-Smirnov menggunakan taraf signifikansi $(a=0,05)$. Kriteria data dikatakan berdistribusi normal adalah apabila $\operatorname{sig}<a=$ 0,05 . Output uji normalitas hasil belajar peserta didik dengan menggunakan SPSS.

Berdasarkan Uji Kolmogorov-Smirnov tersebut, diketahui bahwa hasil belajar peserta didik dengan penggunaan model pembelajaran Role Playing memperoleh nilai sig sebesar 0,000 dan Inside Outside Cicrle memperoleh nilai sig sebesar 0,000 pada lampiran hal....

\section{2) Uji Homogenitas Data}

Uji homogenitas bertujuan untuk mengetahui apakah data dalam penelitian ini memiliki varians yang sama (homogen) atau tidak. Setelah dilakukan pengelolaan data dengan menggunakan tekhnik tes Homogenety of varience diperoleh nilai signifikansi untuk uji homogenitas sebagai berikut: 
Tabel Uji Homogenitas

\section{Test of Homogeneity of Variances}

Hasil Belajar Siswa

\begin{tabular}{|l|l|l|l|}
\hline $\begin{array}{l}\text { Levene } \\
\text { Statistic }\end{array}$ & df1 & df2 & Sig. \\
\hline 5.935 & 1 & 38 & .020 \\
\hline
\end{tabular}

Berdasarkan tabel diatas diperoleh nilai sig. sebesar 0,20. Dimana nilai sig 0,20 >0,05. Jadi dapat disimpulkan bahwa data dari kelas IV A dan kelas IV B memiliki varians yang sama atau homogen.

\section{B. Pembahasan}

Pembelajaran IPS seperti mata pelajaran lainnya, dapat diajarkan dengan berbagai model atau metode, ketepatan pemilihan model atau metode adalah kunci keberhasilan pembelajaran. Pelibatan peserta didik dalam proses pembelajaran merupakan hasil dari model pembelajaran yang digunakan guru, model atau metode yang tepat dalam melibatkan peserta didik aktif dapat meningkatkan pemahaman siswa terhadap pembelajaran IPS di sekolah.

Penelitian ini telah menemukan gambaran tingkat hasil belajar IPS peserta didik sebelum dan sesudah penerapan model pembelajaran Role Playing dan Inside-Outside Circle (IOC) bahwa setelah diberikan penerapan model kooperatif tipe Role Playing dan InsideOutside Circle (IOC) masing-masing sebanyak 2 kali pertemuan, maka hasil belajar peserta didik mengalami peningkatan. Hal ini dapat dilihat dari tingkat hasil belajar siswa sebelum dan sesudah diberikan penerapan model kooperatif tipe Role Playing dan Inside-Outside Circle (IOC).

Hasil pretest sebelum menggunakan model Role Playing yaitu tidak ada peserta didik pada kategori sangat tinggi dan tinggi, pada kategori sedang terdapat 4 orang peserta didik atau $20 \%$, kategori rendah 4 orang atau $20 \%$, dan kategori sangat rendah sebanyak 12 orang atau $60 \%$. Dan hasil posttest setelah menggunakan model Role Playing yaitu pada kategori sangat tinggi sebanyak 17 orang atau
$85 \%$, kategori tinggi sebanyak 3 orang atau $15 \%$, dan $0 \%$ pada kategori sedang, rendah dan sangat rendah.

Teori yang mendukung penggunaan model Role Playing dalam pembelajaran IPS terhadap hasil belajar peserta didik adalah teori belajar Vigotsky, dimana Vigotsky menyatukan bahwa "Interaksi sosial dengan teman lain memacu terbentuknya ide baru dan memperkaya perkembangan intelektual siswa". Jadi memang model Role Playing ini memiliki pengaruh terhadap hasil belajar peserta didik, seperti pada penelitian sebelumnya dimana pada penelitian :

Lestari, Anita. 2012. Peningkatan Hasil Belajar IPS Melalui Model Pembelajaran Role Playing Bagi Murid Kelas IV SDN Plosoarang 01 Kabupaten Blitar. Skripsi, Jurusan Kependidikan Sekolah Dasar dan Prasekolah, Fakultas Ilmu Pendidikan, Universitas Negeri Malang. Hasil penelitiannya menunjukkan bahwa pelaksanaan kegiatan pembelajaran IPS melalui model pembelajaran Role Playing dapat meningkatkan hasil belajar dengan rata-rata pretest 68 sedangkan posttest 82 ".

Sedangkan Hasil pretest sebelum menggunakan model Inside Outside Circle yaitu tidak ada peserta didik pada kategori sangat tinggi dan tinggi atau $0 \%$, pada kategori sedang terdapat 3 orang peserta didik atau $15 \%$, kategori rendah 5 orang atau $25 \%$, dan kategori sangat rendah sebanyak 12 orang atau $60 \%$. Dan hasil posttest setelah menggunakan model Inside Outside Circle yaitu pada kategori sangat tinggi sebanyak 12 orang atau $60 \%$, kategori tinggi sebanyak 8 orang atau $40 \%$, dan tidak ada peserta didik atau $0 \%$ yang berada pada kategori sedang, rendah dan sangat rendah

Teori Pembelajaran Jean Piaget. Penerapan model pembelajaran tipe IOC ini sejalan berdasarkan teori kontruktivisme, dimana pada dasarnya setiap individu sejak kecil sudah memiliki kemampuan untuk mengkonstruksikan pengetahuannya sendiri. Pengetahuan yang dikontruksikan oleh anak sebagai subjek, maka akan menjadi pengetahuan yang bermakna. Jadi memang model Inside Outside ini memiliki pengaruh terhadap hasil belajar peserta didik berdasarkan hasil belajar di atas, dan juga dapat dilihat pada penelitian sebelumnya dimana pada penelitian :

"Ni Km. Tri Virgawati, I Md.Suarjana, Dw Nym. Sudana. 2017. Hasil penelitian 
sebelum diterapkan model Inside Outside Circle nilai rata-rata 15,73 dan setelah diterapkan model pembelajaran Inside Outside Circle mengalami peningkatan dengan nilai rata-rata sebesar 24,95".

Kemudian hasil perhitungan statistik deskriptif menunjukkan ada perbandingan antara hasil belajar sebelum menggunakan model pembelajaran Role Playing (pretest) yaitu dengan nilai rata-rata 52 , kemudian setelah menggunakan model pembelajaran Role Playing (posttest), hasil belajar peserta didik mengalami peningkatan dengan nilai rata-rata 94. Sedangkan hasil belajar sebelum menggunakan model pembelajaran Inside Outside Circle (pretest) yaitu dengan nilai rata-rata 52, kemudian setelah menggunakan model pembelajaran Inside Outside Circle (posttest), hasil belajar peserta didik mengalami peningkatan dengan nilai rata-rata 91 .

Berdasarkan hasil uji hipotesis menggunakan SPSS SPSS versi 23, diperoleh nilai hasil belajar IPS peserta didik setelah penggunaan model pembelajaran Role Playing dan Inside Outside Circle dengan sig $(0,000)$. Berdasarkan kriteria diatas nilai sig $(0,000)<$ $\mathrm{a}=0,05$, maka dapat dikatakan bahwa terdapat perbedaan antara hasil pretest dan posttest dengan penggunaan model pembelajaran Role Playing dan Inside Outside Cicrle terhadap hasil belajar IPS peserta didik kelas IV SDN 008 Camba - camba Kabupaten Polewali Mandar. Nilai sig $(0,000)<\mathrm{a}=0,05$, maka maka $\mathrm{H}_{0}$ ditolak dan $\mathrm{H}_{1}$ diterima, yaitu terdapat pengaruh model pembelajaran Role Playing dan Inside Outside Cicrle terhadap hasil belajar IPS peserta didik.

Hipotesis 1 :

Diketahui nilai signifikansi untuk variabel $\mathrm{X}_{1}$ (Role Playing) terhadap Y (Hasil belajar IPS) adalah sebesar $0,025<0,05$ dan nilai t hitung $2,158>\mathrm{t}$ tabel 2,086 sehingga dapat disimpulkan bahwa $\mathrm{H}_{1}$ diterima dan $\mathrm{H}_{0}$ ditolak.

Hipotesis 2:

Diketahui nilai signifikansi untuk variabel $\mathrm{X}_{1}$ (Inside Outside Circle) terhadap Y (Hasil belajar IPS) adalah sebesar 0,039<0,05 dan nilai $\mathrm{t}$ hitung 2,298 $>\mathrm{t}$ tabel 2,086 sehingga dapat disimpulkan bahwa $\mathrm{H}_{1}$ diterima dan $\mathrm{H}_{0}$ ditolak.

Hipotesis 3 :

Diketahui nilai signifikansi untuk variabel $\mathrm{X}_{2}$ (Inside Outside Circle) terhadap Y
(Hasil belajar IPS) adalah sebesar 0,039 $<0,05$ dan nilai thitung 2,298 $>\mathrm{t}$ tabel 2,086 sehingga dapat disimpulkan bahwa $\mathrm{H}_{1}$ diterima dan $\mathrm{H}_{0}$ ditolak.

ANOVA $^{a}$

\begin{tabular}{|c|c|c|c|c|c|}
\hline Model & $\begin{array}{l}\text { Sum of } \\
\text { Square } \\
\text { s }\end{array}$ & $\mathrm{df}$ & $\begin{array}{l}\text { Mean } \\
\text { Square }\end{array}$ & $\mathrm{F}$ & Sig. \\
\hline $\begin{array}{ll}1 & \text { Regre } \\
& \text { ssion } \\
& \text { Resid } \\
& \text { ual } \\
& \text { Total }\end{array}$ & \begin{tabular}{|l|}
425.83 \\
4 \\
1029.1 \\
66 \\
1455.0 \\
00
\end{tabular} & $\begin{array}{l}2 \\
17 \\
19\end{array}$ & $\begin{array}{l}212.91 \\
7 \\
60.539\end{array}$ & $\begin{array}{l}3.59 \\
7\end{array}$ & $\mathrm{~b}^{049}$ \\
\hline
\end{tabular}

a. Dependent Variable: Hasil Belajar

b. Predictors: (Constant), Role Playing, Inside Outside Circle

Berdasarkan tabel ANOVA diatas diketahui nilai signifikansi untuk pengaruh $X_{1}$ dan $\mathrm{X}_{2}$ secara simultan terhadap variabel $\mathrm{Y}$ adalah sebesar : sig. 0,049 $<0,05$ dan nilai $\mathrm{F}$ hiting 3,597 $>$ F tabel 3,55. Sehingga dapat disimpulkan bahwa Hipotesis ke 3 diterima yang berarti terdapat pengaruh $\mathrm{X}_{1}$ dan $\mathrm{X}_{2}$ secara simultan terhadap variabel $\mathrm{Y}$.

\section{Model Summary}

\begin{tabular}{|l|l|l|l|l|}
\hline $\begin{array}{l}\text { Mod } \\
\text { el }\end{array}$ & $R$ & $\begin{array}{l}\text { R } \\
\text { Square }\end{array}$ & $\begin{array}{l}\text { Adjusted } \\
\text { R Square }\end{array}$ & $\begin{array}{l}\text { Std. Error } \\
\text { of the } \\
\text { Estimate }\end{array}$ \\
\hline 1 & $.541^{\mathrm{a}}$ & .793 & .759 & 7.781 \\
\hline
\end{tabular}

a. Predictors: (Constant), Role Playing, Inside Outside Circle

Berdasarkan output tabel model summary di atas dapat diketahui nilai $\mathrm{R}$ square sebesar 0,793 , hal ini mengandung arti bahwa pengaruh variabel $\mathrm{X}_{1}$ dan $\mathrm{X}_{2}$ secara simultan terhadap variabel $\mathrm{Y}$ adalah sebesar $79 \%$.

\section{SIMPULAN DAN SARAN}

\section{A. Kesimpulan}

Berdasarkan hasil analisis data secara deskriptif maupun inferensial dan pembahasan hasil penelitian maka dikemukakan kesimpulan sebagai berikut:

1. Hasil belajar IPS sebelum pelaksanaan model pembelajaran Role Playing 
umumnya berada pada kategori rendah, setelah diberi perlakuan dengan menggunakan model pembelajaran Role Playing, hasil belajar peserta didik meningkat menjadi kategori tinggi. Hasil belajar yang meningkat karena model pembelajaran Role Playing ini dilakukan dengan cara bermain peran, yaitu guru membentuk peserta didik menjadi beberapa kelompok kemudian masing-masing kelompok diberikan arahan untuk memainkan kegiatan role playing ini, jadi peserta didik disini memiliki peran masing-masing dan ini disesuaikan dengan materi pelajaran yang sedang berlangsung. Jadi penggunaan model Role Playing.

2. Terjadi peningkatan hasil belajar yang signifikan pada peserta didik setelah diterapkan model pembelajaran Inside Outside Circle. Peningkatan hasil belajar peserta didik terlihat dari data posttest yang meningkat dari sebelum adanya perlakuan. Ini berarti pelaksanaan model pembelajaran Inside Outside Circle berpengaruh terhadap hasil belajar IPS peserta didik kelas IV SDN 008 Camba-camba Kabupaten Polewali Mandar.

3. Jadi intinya penggunaan model pembelajaran Role Playing dan Inside Outside Circle memiliki pengaruh terhadap hasil belajar IPS SDN 008 Camba-camba Kabupaten Polewali Mandar.

\section{B. Saran}

Sesuai dengan kesimpulan tersebut, maka dapat diajukan beberapa saran yaitu :

1. Guru hendaknya dalam proses pembelajaran jangan hanya menggunakan model pembelajaran yang monoton saja, tapi mengganti model pembelajaran secara bervariasi agar peserta didik tidak bosan dan tetap semangat saat proses belajar mengajar berlangsung yaitu menggunakan model pembelajaran Role Playing atau Inside Outside Circle, karena kedua model ini sama-sama memiliki manfaat masingmasing dalam membuat suasana belajar dalam kelas lebih mengasyikkan untuk peserta didik.
2. Sebagai tindak lanjut penggunaan model pembelajaran Role Playing dan Inside Outside Circle ini, pada saat proses pembelajaran diharapkan guru untuk lebih membimbing peserta didik dalam bekerja kelompok saat menerapkan salah satu dari kedua model pembelajaran ini, sehingga dapat menciptakan suasana belajar yang menyenangkan dan peserta didik semangat dalam belajar.

\section{DAFTAR RUJUKAN}

Abustam, M.I, dkk. 2006. Pedoman Praktis Penelitian dan Penulisan Karya Ilmiah. Makassar: Badan Penerbit Universitas Negeri Makassar.

Achmad Rifa'I dan Chatarina Tri Anni.2009, Psikologi pendidikan.Semarang Unnes Press.

Anni, Catharina Tri. 2009. Psikologi Belajar. Semarang : UNNES.

Arends, Richard I. 2008. Leaning To Teach. Belajar untuk Mengajar. Yogyakarta: Pustaka Pelajar.

Arikunto, S. (2003). Dasar-dasar evaluasi pendidikan (edisi revisi). Jakarta: PT Rineka Cipta

Arikunto, Suharsimi 2012. Dasar Dasar Evaluasi Pendidikan. Edisi revisi. Jakarta: Bumi Aksara.

Arikunto, Suharsimi. 1986. Prosedur Penelitian Suatu Pendekatan Praktek. Jakarta: Binaksara.

Bobby De Porter \& Mike Hemacki, dkk. 2000. Quantum Learning. Kaifa. Bandung.

Bloom, Benjamin S., etc. 1956. Taxonomy of Educational Objectives : The Classification of Educational Goals, 
Nurhaida Rahman. Pengaruh Model Pembelajaran Role Playing dan Inside Outside Circle Terhadap Hasil Belajar IPS Peserta Didik SDN 008 Camba - Camba Kabupaten Polewali

Mandar

Handbook I Cognitive Domain. New York : Longmans, Green and Co.

Depdiknas .2003. Undang-undang RI No.20 tahun 2003.tentang sistem pendidikan nasional.

Depdiknas. 2008. KTSP. Hasil Belajar. Jakarta: Depdiknas.

Djodjo Suradisastra, dkk. (1991). Pendidikan IPS III. Jakarta: Depdikbud.

Enok Maryani, Helius Syamsudin. (2009). "Pengembangan

Program Pembelajaran Meningkatkan IPS untuk Keterampilan Sosial". Jurnal Penelitian. Vol. 9. No. 1, 5.

Gunawan, Rudi (2011). Pendidikan IPS Filosofi, Konsep dan Aplikasi. Bandung: Alfabeta.

Huda, M. 2013. Model-model pengajaran dan pembelajaran. Yogyakarta: Pustaka Pelajar.

Ibrahim, H. Muslimin. 2000. Pembelajaran Kooperatif. Surabaya: UNNESA University Press.

Hasan, Hamid. 2009. Pembelajaran Pendidikan IPS di Sekolah Dasar. dala

http://www.pembelajaran.wordpress. com/ Internet diakses tanggal 22 Maret 2018.

Lestari, Anita. 2012. Peningkatan Hasil Belajar PKn Melalui Model Pembelajaran Role Playing Bagi Siswa Kelas III SDN Plosoarang 01 Kabupaten Blitar. Skripsi, Jurusan Kependidikan Sekolah Dasar dan Prasekolah, Fakultas Ilmu Pendidikan, Universitas Negeri Malang. (online). (http://penelitiantindakankelas07.blo gspot.com/2014/04/hasil-belajarsiswa.html?m=1, diakses 12 Februari 2018)

Lie, Anita. 2008. Cooperative Learning. Mempraktikkan Cooperative Learning di Ruang-Ruang Kelas. Jakarta: PT. Grasindo.

Kagan. 2004. Pembelajaran Pendidikan IPS di Sekolah Dasar. dalam http://www.pembelajaran.wordpress. com/ Internet diakses tanggal 22 Maret 2018.

Moedjiono, Moh. Dimyati. 1991/1992. Strategi Belajar Mengajar.

Depdikbud Direktorat Jendral Pendidikan Tinggi Proyek Pembinaan Tenaga Kependidikan.

Nani, Rosdijati. dkk. 2010. Praktik Paikem IPS SD. Jakarta: Erlangga

Nasution Sumaatmadja. (2002). definisi IPS. Jakarta: Bumi Aksara.

Nurhadi. 2004. Pembelajaran Kontekstual dan Penerapannya dalam KBK. Malang : Universitas Negeri Malang.

Ni Km. Tri Virgawati, I Md.Suarjana, Dw Nym. Sudana. 2017. Pengaruh Model Pembelajaran Kooperatif Tipe Inside Outside Circle Terhadap Hasil Belajar Ips Siswa Kelas V. Singaraja: E-Journal Pgsd Universitas Pendidikan Ganesha Mimbar Pgsd, 5 (2).

Purwanto 2010. Evaluasi Hasil Belajar. Yogyakarta: Pustaka Belajar.

Rosdiani, Dini. (2012). Perencanaan Pembelajaran Dalam Pendidikan 
Nurhaida Rahman. Pengaruh Model Pembelajaran Role Playing dan Inside Outside Circle Terhadap Hasil Belajar IPS Peserta Didik SDN 008 Camba - Camba Kabupaten Polewali

Jasmani dan Kesehatan. Bandung: Alfabeta.

Riduwan. 2010. Belajar Mudah Penelitian. Bandung: Al Fabeta.

Sanjaya, Wina. 2009. Perencanaan dan Desain Sistem Pembelajaran.Jakarta : Kencana.

Sanjaya, Wina. 2010. Strategi Pembelajaran Berorientasi Standar Proses. Pendidikan. Jakarta : Prenada Media Group.

Santoso, Singgih. 2011. Statistik Deskriptif: Konsep dan Aplikasi dengan Microsoft Exel dan SPSS. Yogyakarta: ANDI.

Sapriya, dkk, Konsep Dasar IPS, Bandung: UPI Press, 2006.

Spencer, Kagan. (1993). Cooperative Learning. San Juan Capistrano, Kagan Cooperative Learning.

Sudjana. 2009. Metode Statistika. Bandung: Tarsito.

Sugihartono, dkk. .2007. Psikologi Pendidikan. Yogyakarta : UNY Press.

Sugiyono. (2008). Metode penelitian pendidikan (pendekatan kuantitatif, kualitatif, dan $R \& D)$. Bandung: Alfabeta.Sugiyono.2010. Statistik untuk Penelitian. Bandung: Alfa Beta.

Sugiyono. 2011. Metode Penelitian Kuantitatif, Kualitatif dan $R \& D$. Bandung: Afabeta.

Sumantri, Numan. (2001). Pembaharuan Pendidikan IPS. Bandung : Rosda Karya.
Suparno. 2001. Membangun Kompetensi Belajar. Jakarta: Publisher.

Suprijono, Agus. 2011. Model-Model Pembelajaran. Jakarta: Gramedia Pustaka.

Suprijono, Agus. 2011. Cooperative Learning Teori \& Aplikasi Paikem. Yogyakarta: Pustaka Belajar.

Zaini, Hisyam dkk. 2008. Strategi Pembelajaran Aktif. Yogyakarta: Pustaka Ihsan Madani. 